DOI: https://doi.org/10.31874/2309-1606-2019-24-1-128-141

УДК 316.73: 37.017.7

\title{
Валентин ПОМОГАЙБО
}

\section{ФІЛОСОФІЯ жИТТЯ в УСПІШНИХ СПІЛЬНОТАХ}

У тебе можуть забрати твій дім, твій бізнес і навіть твою батьківщину, але не твою освіту - тому навчайся ще старанніше.

(Кредо найбільш успішних іммігрантських спільнот у США)

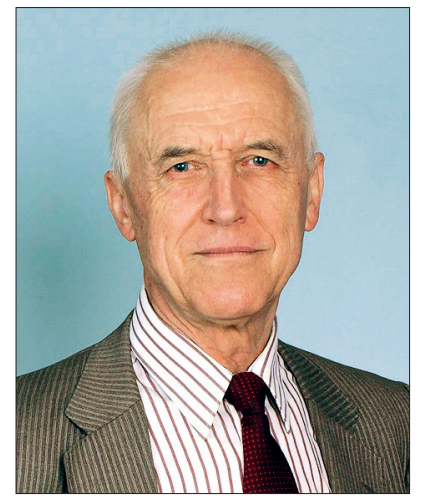

\section{Анотація}

Історичний досвід і наукові дослідження свідчать, що як життєвий успіх окремої людини, так і процвітання країни та рівень життя їі населення залежить не від якості освіти самої по собі, а від їі результативності. Результативність освіти, у свою чергу, визначається суспільною продуктивністю науки, яку можна елементарно презентувати таким простим показником як кількість Нобелівських лауреатів. Абсолютно провідне місце серед країн світу за цим критерієм займають США. Таким чином, США є тією країною, яка здатна максимально забезпечити розвиток людини, а головне - реалізацію їі природних задатків та набуття відповідного матеріального добробуту. Про це свідчить не тільки високий рівень розвитку науки, а й феномен успішності низки іммігрантських спільнот порівняно з європейським населенням Америки. Найбільш успішними етнічними групами в США є євреї, індійці, китайці, нігерійці, кубинці, іранці та ліванці. Особливо вражає успіх нігерійців та кубинців на тлі порівняно незначних досягнень темношкірих та латиноамериканських мешканців США. Виявлено, що усім найбільш успішним етнічним групам Америки притаманні три ментальні особливості: відчуття вищості, загроженість і контроль імпульсів. Відчуття вищості полягає у глибокій внутрішній упевненості у винятковості своєї спільноти порівняно з іншими. Ця упевненість може базуватися на релігії, величній історії та культурі, походженні тощо. Під загроженістю розуміється тривожна невпевненість у свойй значимості в суспільстві, стурбованість стосовно недостатності результатів своєї діяльності. Ключовими джерелами загроженості є презирство з боку інших спільнот, страх та тиск з боку батьків. Презирство з боку населення чужої країни і власне обурення з цього приводу може бути найпотужнішою спонукою для зростання. Другим джерелом загроженості є страх бути нездатним вижити у чужій країні, який може викликати відчай, параліч волі, капітуляцію, навіть сором. Але він також може спричинити зовсім іншу реакцію - спонуку піднятися, заробити гроші, досягти влади, щоб або стати успішним тут, або мати засоби 
для втечі. Третім і найбільш поширеним джерелом загроженості в успішних іммігрантських спільнотах є тиск батьків на дітей, спрямований на досягнення успіху. Батьки виховують у дітей переконання, що успіх, передусім у навчанні, є обов'язком честі родини, а також захистом від непевного та ворожого світу. Контроль імпульсів означає здатність протистояти різним спокусам, особливо спокусі відмовитися від труднощів та кинути важке завдання замість того, щоб його виконати. Жодне людське суспільство не може існувати без контролю імпульсів. Однак треба пам'ятати, що окремо взятий контроль імпульсів - це просто марний аскетизм. Успіх можливий лише внаслідок поєднання усіх трьох засад - відчуття вищості, загроженості та контролю імпульсів. Філософія успішного життя є надзвичайно ефективним засобом досягнення високого суспільного статусу, якщо він для вас важливий. Однак нею варто користатися тільки для того, щоб досягти успіху. Після цього необхідно позбутися філософії успіху, бо надалі вона може спричинити патологічну спонуку до крайнощів. Досвід виховання дітей в успішних спільнотах Америки незаперечно буде корисним у справі сучасного ребормування української освіти.

Ключові слова: філософія життя, якість освіти, результативність освіти, успішні спільноти, відчуття вищості, загроженість, презирство, страх, тиск батьків, контроль імпульсів, реформування української освіти.

Вступ. Успішне життя людини можливе лише в суспільстві, яке спроможне забезпечити її духовний, культурний та освітній розвиток, реалізацію її природних задатків та набуття відповідного матеріального добробуту. За критерій такої спроможності доцільно взяти не індекс рівня життя чи індекс якості освіти, які мають складний розрахунок і свідчать не про рівень успішності життя, а лише про загальний рівень життя та освіченості населення країни відповідно (Puskorius, 2015; Education index, 2018). Але життєвий успіх і навіть загальний рівень життя населення залежить не від якості освіти самої про собі, а від її результативності. Результативність освіти, у свою чергу, визначається суспільною продуктивністю науки, яку можна елементарно презентувати таким простим показником як кількість Нобелівських лауреатів. Провідне місце за цим критерієм серед країн світу займають США. За весь період існування Нобелівської Премії (1901-2018) загальна світова кількість нагороджених нею становить 935 осіб, із яких громадянами США одержано 377 Премій, тобто 40,3\% (All Nobel Prizes, 2019; List of Nobel laureates by country, 2019). Таким чином, США $€$ тією країною, яка здатна максимально забезпечити духовний, культурний та освітній розвиток людини, а головне - реалізацію її природних задатків та набуття відповідного матеріального добробуту. Про це свідчить не тільки високий рівень розвитку науки, а й феномен успішності низки іммігрантських спільнот порівняно з корінним європейським населенням Америки. 
Успішні спільноти Америки. Найбільш успішними етнічними групами в США є євреї, індійці, китайці, нігерійці, кубинці, іранці та ліванці. Особливо вражає успіх нігерійців та кубинців на тлі порівняно незначних досягнень темношкірих та латиноамериканських мешканців США (Chua, 2015: 50). Варто також назвати мормонів, які всього за кілька десятиліть пройшли шлях від середнього і навіть убогого рівня життя до вершин корпоративного успіху (Ostling, 2007: 137-143; Bowman, 2012: 223-225).

Значна більшість сучасних євреїв у США - американці у третьому, четвертому і п'ятому поколінні (Family, American Jewish, 2018). Переважно це діти висококваліфікованих професіоналів - юристів, лікарів, банкірів тощо. Вони матеріально добре забезпечені (Burstein, 2007; American Jews, 2018), складають значну частину політичної, економічної, наукової та культурної еліти країни і відчувають себе справжніми американцями (Dershowitz, 1997: 1-2).

Євреї у США займають верхні щаблі не лише за стандартними показниками - престижна робота, доходи родин, капітали тощо. Попри їхню крихітну частку в населенні країни (2\%), їх неймовірно багато серед найвизначніших американських державних діячів різних рівнів (у тому числі майже 40 сенаторів), правників, науковців (136 Нобелівських Премій, тобто 36\% усіх Премій США), письменників, поетів, акторів, музикантів (Category: Lists of American Jews, 2019; List of Jewish Nobel laureates, 2018). Це означає, що євреї у США пройшли шляхом успішного життя далі, ніж інші винятково успішні спільноти. Наприклад, вони на три покоління випереджають американців азійського походження, хоча зазнавали і зазнають тиску спільних для всіх іммігрантів чинників - асиміляції, змішаних шлюбів, занепаду внаслідок зменшення сили мотивації виживання внаслідок життєвого успіху і матеріальних статків. Причина цього в тому, що єврейська спільнота Америки продовжує і надалі добре усвідомлювати свою унікальну історію, культивувати відчуття своєї обраності та постійної небезпеки через неприязнь інших людей, гоніння і навіть загрозу життю, внаслідок чого зуміла спрямувати свої нові можливості та свою природну енергію на новий шлях досягнення успіху (Chua, 2015: 159-160).

Серед успішних спільнот також виділяються вихідці із ПівденноСхідної Азії - індійці та китайці, частка яких у населенні США дещо менша, ніж євреїв: 1,3\% та 1,5\% відповідно (Indian Americans, 2019; Chinese Americans, 2019). Вони найбільш освічені, мають високі доходи і відіграють у житті країни все більшу роль. Правда, кількість Нобелівських лауреатів серед них незначна - всього лише 4 індійця та 8 китайців. Вражає кількість індійців серед президентів, деканів та професорів американських університетів, а також науковців з математики, економіки 
і комп’ютерних технологій. Китайці вчені відзначаються у галузі медицини, біології та комп'ютерних технологій. Представники цих азійських спільнот досить помітні серед американських державних діячів різних рівнів, бізнесменів, письменників, музикантів, акторів, спортсменів тощо (List of Indian Americans, 2019; List of Chinese Americans, 2018).

Проблема філософії життя в успішних спільнотах США найбільш повною мірою на цей час досліджена американськими правниками Емі Чуа та Джедом Рубенфельдом у монографії «Потрійна упаковка: як три малоймовірні ознаки пояснюють піднесення та занепад культурних груп в Америці» (Chua, 2015), яка видана також українською мовою (Чуа, 2017). Було виявлено, що усім найбільш успішним етнічним групам Америки притаманні три ментальні особливості: відчуття вищості, загроженість і контроль імпульсів (Chua, 2015: 12-14).

Відчуття вищості. Відчуття вищості полягає у глибокій внутрішній упевненості в особливості, винятковості або перевагах своєї спільноти порівняно з іншими. Ця упевненість може мати різні джерела. Таким джерелом може бути релігія, як у мормонів. У китайців та персів відчуття вищості коріниться у величній історії та культурі цих народів. Частина індійців пишається своїм походженням із священицької касти брахманів, а численні нігерійські іммігранти - приналежністю до відомого практичного та діловитого племені іґбо. Відчуття вищості у євреїв базується на кількох засадах - обраності, моральності, інтелекту, поважання законів та здатності виживати всупереч презирству, ворожості, погромів і навіть геноциду (Chua, 2015: 12-13).

Звичайно, ця одіозна властивість людської природи суперечить основній ліберальній ідеї про рівність усіх людей незалежно від кольору шкіри, способу життя чи переконань. Окремі особи з відчуттям вищості у суспільстві сприймаються негативно, а групова демонстрація вищості осуджується як джерело нацизму, расизму, колоніалізму або імперіалізму. Відчуття вищості можна виправдати дише як засіб захисту малих етнічних спільнот від ворожості та упереджень більшості населення. Адже лише за таких умов малі етнічні групи мають найбільше можливостей вижити, дотримуючись своїх уявлень про себе, своїх цінностей і переконань (Horowitz, 1985: 62; Dershowitz, 1997: 30-31, 72). Успішні спільноти Америки значною мірою різняться між собою за глибиною та силою відчуття вищості.

Найбільш значне відчуття вищості у китайців (Wang, 1999; Guo, 2004: 83-84). Навіть назва Китаю китайською мовою - Чжунго означає «центр світу» або «центр цивілізації». Китайське відчуття вищості було сформоване внаслідок поєднання особливих історичних обставин. У далекому минулому Китай - політично, технологічно і культурно розвинена країна з писемністю - протягом тисячоліть за сусідів мав численні на- 
півдикі кочові племена. Звичайно, за таких умов китайці вважали себе вищими за сусідів, яких вони поступово асимілювали (Wang, 1999). Ocoбливого розквіту китайська цивілізація досягла за династії Мін (13691644) (Kennedy, 1988: 4-9; Chua, 2007: 178-181). У ту епоху населення Китаю (понад 100 млн. осіб) було вдвічі чисельнішим за сукупне населення країн Європи. Європа лише почала відроджуватися після мороку Середньовіччя, а Китай уже мав найрозвиненішу у світі металургію, друкарство, паперові гроші, порох. Китайський флот нараховував понад 4000 суден, серед яких були такі, що могли вмістити 1000 пасажирів і перевозити в 400 разів більше вантажів, ніж найбільші європейські кораблі. Для порівняння: військовий флот, відряджений королем Англії Генріхом V (XV ст.) на завоювання Франції, складався всього із 4 суден, кожне із яких могло перевезти через Ла-Манш лише 100 вояків.

У євреїв наявне власне відчуття вищості порівняно з іншими етносами. Вони вважають себе обранцями Бога. Це переконання незрозуміле і дещо таємниче, бо ніде у Старому Заповіті про це мова не йде. Навпаки, Бог називає євреїв корумпованими, збоченими, невірними і народом без сенсу (Біблія, 1988: 75-275). Але єврейський народ протягом всієї своєї історії перед лицем неймовірних поневірянь, неприязні, зневаги і прямого геноциду проніс впевненість, що він $є$ обранцем Бога (Gitlin, 2010: 15-16). Феномен єврейської богообраності в наш час став неістотним, бо був витіснений ідеєю історичної місії євреїв (Israel, 1994: 74-77). Ця ідея стверджує, що найактивнішими творцями сучасної цивілізації були лише два маленькі народи - греки та євреї. До того ж євреї подарували світові три найбільші релігії, шанування закону і найдосконаліші засади моралі, а в основі Конституції США лежить єврейська концепція права. Навіть переслідування, яких зазнав цей народ, були корисні, бо сформували у нього міцну витримку, самоконтроль і жертовність.

Загроженість. Під загроженістю в даному контексті розуміється тривожна невпевненість у своїй значимості та ролі в суспільстві, стурбованість стосовно недостатності результатів своєї діяльності. Загроженість може набувати різних форм: відчуття пригніченості, небезпеки чи власної недосконалості, страх втратити те, що маєш. Іммігрантські етнічні спільноти, як і окремі пересічні особи, в різній мірі відчувають загроженість. Одні схильні до цього менше, інші - більше. Становище іммігранта само по собі небезпечне, бо він загрожений вже тим, як вижити в чужій, неприязній країні та дати своїм дітям гідне життя. Разом з тим, приниження, кепкування та підозріле ставлення можуть викликати потужну мотивацію для соціального зростання. Ключовими джерелами загроженості $є$ презирство з боку інших спільнот, страх та тиск батьків (Chua, 2015: 13, 72). 
Презирство з боку населення чужої країни і власне обурення з цього приводу може бути найпотужнішою спонукою для зростання. Це добре продемонструвала перша хвиля кубинських емігрантів (60-ті роки $\mathrm{XX}$ ст.), третина яких була професіональною та управлінською елітою на Кубі, але у США вимушена була задовольнятися будь-якою роботою, переважно як промислові робітники і домашні слуги. Ці матеріально добре забезпечені люди, яких Ф. Кастро назвав «піною Землі та непотрібними черв'яками», не могли дозволити собі бути пасивними. Вони свідомо взяли на себе місію довести, що переконання кубинського комуністичного диктатора помилкові (Gonzalez-Pando, 1998: 36, 46-47). Подібне пережили в Америці також іранські іммігранти після ісламської революції 1979 р. в Ірані (Mobasher, 2012: 8).

Другим джерелом загроженості $\epsilon$ страх бути нездатним вижити у чужій країні. Небезпеки, реальні чи уявні, страх, раціональний чи ірраціональний, поєднуються у іммігрантів з матеріальними турботами та загальною глибокою стривоженістю. Переслідування може викликати різні психологічні реакції - відчай, параліч волі, капітуляцію, навіть сором. Але воно також може спричинити зовсім іншу реакцію - спонуку піднятися, заробити гроші, досягти влади, щоб або стати успішним тут, або мати засоби для втечі (Isaacson, 1992: 56). Численні кубинці та африканці, які втікали від репресивних режимів у своїх країнах, втратили все, перш ніж вони прибули до США. У багатьох іммігрантських громадах США батьки передають своїм дітям відчуття життєвої небезпеки: «У тебе можуть забрати твій дім, твій бізнес і навіть твою батьківщину, але не твою освіту - тому навчайся ще старанніше» (Chua, 2015: 88).

Третім і найбільш поширеним джерелом загроженості в успішних іммігрантських спільнотах $є$ тиск батьків на дітей, спрямований на досягнення успіху (Rumbaut, 2005: 23-59). Батьки виховують у дітей переконання, що успіх, передусім у навчанні, є обов'язком честі родини, а також захистом від непевного та ворожого світу. Крім того, діти іммігрантів постійно відчувають провину за жертви, приниження та поневіряння своїх батьків у чужій країні. Це явище надзвичайно поширене в азійських родинах, насамперед у китайських (Chao, 1996; Louie, 2004: 48, $54,57,60-61)$. Раніше таке переконання було одним із ключових засад єврейської традиції. Однак більшість сучасних євреїв Америки уже не зазнає загроженості і заперечує ці ще недавно традиційні зобов'язання своїх дітей. Звичайно, така тенденція спричинює зниження єврейської успішності (Chua, 2015: 88-90).

Контроль імпульсів. Контроль імпульсів означає здатність протистояти різним спокусам, особливо спокусі відмовитися від труднощів та кинути важке завдання замість того, щоб його виконати. Жодне людське суспільство не може існувати без контролю імпульсів. Рівень контролю 
імпульсів різний у різних спільнотах, як і рівень двох попередніх компонентів запоруки життєвого успіху. Звичайно, контроль імпульсів суперечить поширеному серед американської молоді переконанню про сенс існування людини, яке базується на ідеї максимального смакування життя тут і зараз. До того ж, на жаль, сучасне цивілізоване суспільство надто романтизує дитинство, уявляючи його періодом необмежного задоволення. Воно боїться обмежити це дитяче відчуття навіть помірними труднощами і вимогами дисципліни. Але всупереч цьому кожна із найбільш успішних спільнот Америки з раннього дитинства виховує своїх дітей на засадах дисципліни і контролю імпульсів. У всякому разі, вони це робили на підйомі (Chua, 2015: 14).

Доцільність таких принципів життя підтверджуються результатами численних наукових досліджень, які свідчать, що життєвий успіх людини більшою мірою залежить від волі та витривалості, ніж від коефіцієнта інтелекту чи тесту на здатність до навчання в університеті (Duckworth, 2007; Baumeister, 2011: 1-17; Duckworth, 2011; Duckworth, 2012; McGonigal, 2012: 12; Sullivan, 2013: 57-74). Показано також, що силу волі та наполегливість можна примножувати (Muraven, 1999; Dweck, 2006: 71-74; Oaten, 2006a; Oaten, 2006b; Baumeister, 2011: 11, 124-141; Halvorson, 2011: xvii-xxi).

Здатністю витримувати труднощі добре володіють китайські іммігранти в Америці (Li, 2012: 49-50, 63-65, 91-92, 139-142). Дисципліна, самоконтроль, спротив спокусі скаржитися та припинити зусилля до цього часу залишаються ключовими засадами китайської традиції виховання і навчання дітей (Chao, 1996; Li, 2012: 111-112, 124-125, 129, 145-146, 167-170, 258-260, 267-268; Jen, 2013: 48).

Однак треба пам'ятати, що окремо взятий контроль імпульсів - це просто марний аскетизм. Успіх можливий лише внаслідок поєднання усіх трьох засад - відчуття вищості, загроженості та контролю імпульсів.

Зворотний бік філософії успішного життя. Філософія успішного життя $\epsilon$ надзвичайно ефективним засобом досягнення високого суспільного статусу, якщо він для вас важливий. Однак нею варто користатися тільки для того, щоб досягти успіху. Після цього необхідно позбутися філософії успіху, бо надалі вона може спричинити патологічну спонуку до крайнощів.

Так східно-азійська версія філософії успіху спроможна перетворити життя на тяжкі страждання дитини через батьківські чи власні прагнення, які неможливо виконати, через існування з переконанням, що у світі немає досягнень, які не можна було б поліпшити. Це викликає депресивний стан і тривогу. Тим не менше, вживання алкоголю, наркотиків та куріння тютюну серед азійської молоді найнижче в США (в середньому близько $7 \%$ проти $18 \%$ серед аборигенів та $22 \%$ серед білошкірого 
населення) [SAMHSA, 2014: 25, 38, 52], а рівень самогубств понад удвічі нижчий, ніж у білого населення (5,6 випадків на 100 тис. осіб проти 12,3) (Fatal Injury Reports, 2015).

Для євреїв неконтрольована практика філософії успішного життя небезпечна іншим відхиленням - піддаванням влади сумніву (Johnson, 1987: 295; Patai, 1996: 332), що відображено навіть в Старому Заповіті (Біблія, 1988: 620-665). Внаслідок цього шанування батьків і некритичне схиляння перед їхнім авторитетом в єврейській культурі не поширене (Howe, 1976: 254; Bloom, 1986: 19). Цей виклик будь-якій владі часто $\epsilon$ причиною революційних ідей у філософії, соціології та науці, а також болісних конфліктів та розколів у єврейських родинах.

Крайнощі філософії успіху можуть також спонукати до збагачення лише заради самого збагачення на основі амбіцій або жадібності, що часто виводить на дорогу злочину (Raghavan, 2013: 381, 415).

Висновки. Нині в Україні здійснюється реформування національної освіти, яка не відповідає рівню якості освіти розвинених країн. Цьому процесові приділяють достатню увагу українські науковці. Одні з них порушують питання цінностей, на яких має базуватися «нова українська школа» (Гірний, 2017). Інші вважають, що «реформування шкільної освіти в Україні не повинно обмежуватись програмними документами, а має стати простором педагогічної та соціальної творчості. Тільки у цьому випадку можлива реалізація стратегії модернізації сучасної школи» (Григорова, 2017). Ще інші обгрунтовують концепцію «нового українського вчителя як майстра прокладання траєкторії життєвого шляху особистості» (Довбня, 2018). Щойно опублікована у журналі «Філософія освіти. Philosophy of Education» моя стаття про вельми успішний досвід реформування фінської освіти (Помогайбо, 2018). Все це правильно і надзвичайно важливо для новітнього реформування української школи. Але навіть найдосконаліша освіта - лише засіб, інструмент досягнення успіху в житті як кожного громадянина, так і країни загалом. Для досягнення продуктивних результатів освіти необхідно володіти ефективною технологією користування нею. Адже всі громадяни США, незалежно від расової та соціальної приналежності, користуються однією й тією ж освітою, яка, до того ж, не вважається вельми досконалою на світовому рівні (Best Countries for Education, 2019). Однак, як свідчать факти, наведені в цій статті вище, успішними в освіті та житті в Америці є не громадяни давнього європейського походження, а іммігрантські спільноти із Південно-Східної Азії, Близького Сходу і навіть Африки завдяки традиційним особливостям виховання дітей у своїх родинах. Ключові засади такого виховання можуть також бути корисними для побудови такої української освіти, яка забезпечить життєвий успіх українців, а отже і процвітання України у повному розумінні цього слова. 


\section{Посилання}

Біблія (1988) Ювілейне видання з нагоди тисячоліття християнства в Україні. США: ЕЛМ.

Гірний О.I. (2017) На чому будувати теорію виховання для «нової української школи». Філософія освіти. Philosophy of Education, 2 (21), 98-114.

Григорова Н.В. (2017) Сучасна школа в європейському філософсько-освітньому дискурсі. Філособія освіти. Philosophy of Education, 2 (21), 258-261.

Довбня В.М. (2018) Нова українська школа: спроба філософсько-антропологічного осмислення. Філософія освіти. Philosophy of Education, 1 (22), 240-258.

Помогайбо В.М. (2018) Філософія успішної фінської освіти. Філософія освіти. Philosophy of Education, 2 (23), 270-282

Чуа Е. (2017) Три сили: Як виховують в успішних спільнотах. К.: Yakaboo Publishing.

\section{Referenses}

The Bible (1988) Anniversary edition on the occasion of the Millennium of Christianity in Ukraine. US: ELM [in Ukrainian].

Girnyi OI (2017) On what to build a theory of education for the "new Ukrainian school". Filosofiya osvity.Philosophy of Education, 2 (21), 98-114 [in Ukrainian].

Dovbnya V.M. (2018) The New Ukrainian School: An Attempt at Philosophical and Anthropological Thinking. Filosofiya osvity. Philosophy of Education, 1 (22), 240-258 [in Ukrainian].

Pomagaibo V.M. (2018) The philosophy of successful Finnish education. Filosofiya osvity. Philosophy of Education, 2 (23), 270-282 [in Ukrainian].

Chua E. (2017) Three forces: How to bring up in successful communities. K.: Yakaboo Publishing [in Ukrainian].

All Nobel Prizes (2019) The Nobel Prizes (Official website). URL: https://www.nobelprize. org/prizes/lists/all-nobel-prizes/.

American Jews (2018) Wikipedia, the free encyclopedia. URL: https://en.wikipedia.org/ wiki/American_Jews.

Baumeister, R.F. (2011) Willpower: Rediscovering the greatest human strength / R.F. Baumeister, J. Tierney. NY: Penguin Press.

Best Countries for Education (2019) USNews. 2019. URL: https://www.usnews.com/ news/best-countries/best-education.

Bloom, A. (1986) Prodigal sons: The New York intellectuals and their world. NY: Oxford University Press.

Bowman, M. (2012) The Mormon people: The making of an American faith. NY: Random House.

Burstein, P. (2007) Jewish educational and economic success in the United States: A search for explanations. Sociological Perspectives, 50(2), 209-214.

Category: Lists of American Jews (2019) Wikipedia, the free encyclopedia. URL: https:// en.wikipedia.org/wiki/Category:Lists_of_American_Jews.

Chao, R.K. (1996) Chinese and European American mothers' beliefs about the role of parenting in children's school success. Journal of Cross-Cultural Psychology, 27(4), 403423;

Chinese Americans (2019) Wikipedia, the free encyclopedia. URL: https://en.wikipedia. org/wiki/Chinese_Americans. 
Chua, A. (2007) Day of empire: How hyperpowers rise to global dominance - and why they fall. NY: Doubleday.

Chua, A. (2015) The triple package: How three unlikely traits explain the rise and fall of cultural groups in America / A. Chua, J. Rubenfeld. NY: The Penguin Press.

Chua, A. (2017) Three powers: How to educate in successful communities. Transl. from English / A. Chua, J. Rubenfeld. K.: Yakaboo Publishing [In Ukrainian].

Dershowitz, A.M. (1997) The vanishing American Jew: In search of Jewish identity for the next century. NY: Little, Brown and Company.

Dovbnya, V.M. (2018) New Ukrainian school: an attempt of philosophical and anthropological comprehension. Filosofiya osvity. Philosophy of Education, 22(1), 240-258 [In Ukrainian].

Duckworth, A.L. (2007) Grit: Perseverance and passion for long-term goals / A.L. Duckworth, Ch. Peterson, M.D. Matthews, D. Kelly. J. Pers. Soc. Psychol., 92 (6), 10871110.

Duckworth, A.L. (2011) The significance of self-control.. PNAS, 108(7), 2639-2640.

Duckworth, A.L. (2012) What no child left behind leaves behind: The roles of IQ and selfcontrol in predicting standardized achievement test scores and report card grades / A.L. Duckworth, P.D. Quinn, E. Tsukayama. J. Educ. Psychol., 104(2), 439-451.

Dweck, C.S. (2006) Mindset: The new psychology of success. NY: Random House.

Education index (2018) Wikipedia, the free encyclopedia. URL: https://en.wikipedia.org/ wiki/Education_Index.

Family, American Jewish (2018) Jewish Virtual Library. URL: http://www. jewishvirtuallibrary.org/family-american-jewish.

Fatal Injury Reports (2015) National and Regional, 1999 - 2015. Centers for Disease Control and Prevention, USA, Atlanta, GA. URL: https://webappa.cdc.gov/sasweb/ ncipc/mortrate10_us.html

Gitlin, T. (2010) The chosen peoples: America, Israel, and the ordeals of divine election / T. Gitlin, L. Leibovitz. NY: Simon \& Schuster.

Gonzalez-Pando, M. (1998) The Cuban Americans. Westport, CT, and London: Greenwood Press.

Grygorova, N.V. (2017) The Modern School in the European Educational Philosophy Discourse. Filosofiya osvity. Philosophy of Education, 21(2), 258-261. [In Ukrainian].

Guo, Y. (2004) Cultural nationalism in contemporary China. London: Routledge Curzon.

Halvorson, H.G. (2011) Succeed: How we can reach our goals. NY: Hudson Street Press.

Hirnyi, O.I. (2017) What to build the theory of upbringing for the "New Ukrainian school". Filosofiya osvity. Philosophy of Education, 21(2), 98-114. [In Ukrainian].

Horowitz, D.L. (1985) Ethnic groups in conflict. Berkeley, LA, and London: University of California Press.

Howe, I. (1976) World of our fathers. NY: Harcourt Brace Jovanovich.

Indian Americans (2019) Wikipedia, the free encyclopedia. URL: https://en.wikipedia. org/wiki/Indian_Americans.

Isaacson, W. (1992) Kissinger: A biography. NY: Simon \& Schuster.

Israel, S. (1994) Great Jewish speeches throughout history / S. Israel, S. Forman, eds. Northvale, NJ: Jason Aronson Inc. 
Jen, G. (2013) Tiger riting: Art, culture, and the interdependent self. Cambridge, MA, and London: Harvard University Press.

Johnson, P. (1987) A history of the Jews. N,Y.: Harper \& Row.

Kennedy, P. (1988) The rise and fall of the great powers. London: Unwin Hyman.

Li, J. (2012) Cultural foundations of learning: East and West. Cambridge, UK: Cambridge University Press.

List of Chinese Americans (2018) Wikipedia, the free encyclopedia. URL: https:// en.wikipedia.org/wiki/List_of_Chinese_Americans

List of Indian Americans (2019) Wikipedia, the free encyclopedia. URL: https:// en.wikipedia.org/wiki/List_of_Indian_Americans

List of Jewish Nobel laureates (2018) Wikipedia, the free encyclopedia. URL: https:// en.wikipedia.org/wiki/List_of_Jewish_Nobel_laureates.

List of Nobel laureates by country (2019) Wikipedia, the free encyclopedia. URL: https:// en.wikipedia.org/wiki/List_of_Nobel_laureates_by_country.

Louie, V.S. (2004) Compelled to excel: Immigration, education, and opportunity among Chinese Americans. Stanford, CA: Stanford University Press.

McGonigal, K. (2012) The willpower instinct: How self-control works, why it matters, and what you can do to get more of it. N.Y.: Avery.

Mobasher, M.M. (2012) Iranians in Texas: Migration, politics, and ethnic identity. Austin: University of Texas Press.

Muraven, M. (1999) Longitudinal improvement of self-regulation through practice: building self-control through repeated exercise / M. Muraven, R.F. Baumeister, D.M. Tice. J. Soc. Psychol., 139(4), 446-57.

Oaten M. (2006a) Improved self-control: The benefits of a regular program of academic study / M. Oaten, K. Cheng. Basic App. Soc. Psych., 28(1), 1-16.

Oaten M. (2006b) Longitudinal gains in self-regulation from regular physical exercise / M. Oaten, K. Cheng. Br. J. Health Psychol., 11(4), 717-33.

Ostling, R.N. (2007) Mormon America: The power and the promise / R.N. Ostling, J.K. Ostling. New York: Harper One.

Patai, R. (1996) The Jewish mind. Detroit: Wayne State University Press.

Pomohaibo, V.M. (2018) Philosophy of successful Finnish education. Filosofiya osvity. Philosophy of Education, 22(2) [In Ukrainian].

Puskorius, S. (2015) The methodology of calculation the quality of life index. International Journal of Information and Education Technology, 5(2), 156-159. URL: http://www. ijiet.org/papers/494-S10008.pdf.

Raghavan, A. (2013) The billionaire's apprentice: The rise of the Indian-American elite and the fall of the Galleon Hedge Fund. NY and Boston: Business Plus

Rumbaut, R.G. (2005) Children of immigrants and their achievement: The role of family, acculturation, social class, gender, ethnicity, and school contexts. In Addressing the achievement gap: Theory informing practice. Ed. R.D. Taylor. Charlotte, NC: Information Age Publishing, Inc.

Samhsa (2014) Substance Abuse and Mental Health Services Administration, Results from the 2013 National Survey on Drug Use and Health: Summary of National Findings. URL: https://www.samhsa.gov/data/sites/default/files/NSDUHresultsPDFWHTML2013/ Web/NSDUHresults2013.pdf.

Sullivan B. (2013) The plateau effect / B. Sullivan, H.H. Thomposn. NY: Penguin Press. 
The Bible (1988) Jubilee Edition on the Millennium occasion of Christianity in Ukraine. USA: ELM.

Wang, Q.E. (1999) History, space, and ethnicity: The Chinese worldview. J. World Hist., $10(2), 285-305$.

\section{Валентин Помогайбо. Философия жизни в успешных сообществах}

Исторический опыт и научные исследования показывают, что как жизненный успех отдельного человека, так и процветание страны и уровень жизни ее населения зависит не от качества образования самого по себе, а от его результативности. Результативность образования, в свою очередь, определяется общественной производительностью науки, которую можно элементарно представить таким простым показателем как количество Нобелевских лауреатов. Абсолютно ведущее место среди стран мира по этому критерию занимают США. Таким образом, США являются той страной, которая способна максимально обеспечить развитие человека, а главное - peализацию его природных задатков и приобретение соответствующего материального благосостояния. Об этом свидетельствует не только высокий уровень развития науки, но и феномен успешности ряда иммигрантских сообществ по сравнению с европейским населением Америки. Наиболее успешными этническими группами в США являются евреи, индийцы, китайцы, нигерийцы, кубинцы, иранцы и ливанцы. Особенно поражает успех нигерийцев и кубинцев на фоне сравнительно незначительных достижений темнокожих и латиноамериканских жителей США. Выявлено, что всем наиболее успешным группам Америки присущи три ментальные особенности: убеждение в превосходстве, ощущение угрозы и контроль импульсов. Убеждение в превосходстве заключается в глубокой внутренней уверенности в исключительности своего сообщества по сравнению с другими. Эта уверенность может основываться на религии, величественной истории и культуре, происхождении и т.п. Под ощущением угрозы понимается тревожная неуверенность в своей значимости в обществе, обеспокоенность недостаточностью результатов своей деятельности. Главными источниками ощущения угрозы является презрение со стороны других сообществ, страх и давление со стороны родителей. Презрение со стороны населения чужой страны и собственно возмущение по этому поводу может быть мощной побудительной силой для роста. Вторым источником ощущения угрозы является страх быть неспособным выжить в чужой стране, который может вызвать отчаяние, паралич воли, капитуляцию и даже стыд. Но он также может вызвать совсем другую реакцию - побуждение подняться, заработать деньги, достичь власти, чтобы либо стать успешным здесь, либо иметь средства для побега. Третьим и наиболее распространенным источником ощущения угрозы в успешных иммигрантских сообществах является давление родителей на детей, направленное на достижение успеха. Родители воспитывают у детей убеждение, что успех, прежде всего в обучении, является делом чести семьи, а также защитой от непредсказуемого и враж- 
дебного мира. Контроль импульсов означает способность противостоять различным искушениям, особенно искушению отказаться от трудностей и бросить сложное задание вместо того, чтобы его выполнить. Ни одно человеческое общество не может существовать без контроля импульсов. Однако надо помнить, что отдельно взятый контроль импульсов - это просто бесполезный аскетизм. Успех возможен лишь в результате сочетания всех трех принципов - убеждения в превосходстве, ощущения угрозы и контроля импульсов. Философия успешной жизни является чрезвычайно эффективным средством достижения высокого общественного статуса, если он для вас важен. Однако ею стоит пользоваться только для того, чтобы достичь успеха. В дальнейшем она может вызвать патологическое побуждение к крайностям. Опыт воспитания детей в успешных сообществах Америки неоспоримо будет полезным в деле современного реформирования украинского образования.

Ключевые слова: философия жизни, качество образования, результативность образования, успешные сообщества, убеждение в превосходстве, ощущение угрозы, презрение, страх, давление родителей, контроль импульсов, реформирование украинского образования.

\section{Valentyn Pomohaibo. Philosophy of life in successful community}

Historical experience and scientific researches witness that both an individual's life success and a country's prosperity and the living standard of population depend not on the quality of education itself, but on its effectiveness. The effectiveness of education, in turn, is determined by a social productivity of science, which can be presented elementarily by such a simple indicator as a number of Nobel laureates. The USA holds the leading place among countries in this area. Thus, the United States is the country that can maximally ensure human development, and most importantly - a realization of human natural gifts and an acquisition of appropriate material welfare. This is evidenced not only by the high level of science development, but also by the phenomenon of a success of a number of immigrant communities compared with the US European population. The most successful ethnic groups in the United States are Jews, Indians, Chinese, Nigerians, Cubans, Iranians and Lebanese. Particularly impressive is the success of the Nigerians and Cubans against a background of comparatively small achievements of the African and Latin Americans. It has been found that all most successful ethnic groups in the USA have three mental traits: a superiority complex, an insecurity, and impulse control. The superiority complex lies in deep inner confidence in an uniqueness of your community compared to others. This confidence can be based on religion, majestic history and culture, origin, and so on. Insecurity means anxiety uncertainty in its significance in society, concern about a lack of results of its activities. Key sources of insecurity are scorn by other communities, fear and parents' pressure. A scorn by the people of a strange country and its own indignation in this regard may be the most powerful incentive for growth. The second source of the insecurity is fear of being unable to survive in a strange country, which can 
lead to despair, paralysis of will, capitulation, even shame. But it can also cause a completely different reaction - an urge to rise, earn money, reach power, either to become successful here, or to have same means to escape. The third and most common source of the sense of threat in successful immigrant communities is the pressure from parents to children to be succeed. Parents bring up children's to conviction that success, foremost in learning, is a responsibility of family honor, as well as protection from an uncertain and hostile world. Impulse control means an ability to withstand various temptations, especially the temptation to relinquish difficulty and challenge a difficult task rather than to perform it. No human society can exist without control of impulses. However, it must be remembered that individual control of impulses is just a futile austerity. Success is only possible as a result of combining all three principles - a conviction of superiority, a sense of threat, and an impulse control. Philosophy of a successful life is an extremely effective means of achieving a high social status, if it is important for you. However, it should be used only to succeed. After this it is necessary to get rid of success philosophy, because in the future it can cause a pathological drive to extremes. The experience of bringing up children in the successful communities of America will undoubtedly be useful in the current reforming of Ukrainian education.

Key words: philosophy of life, quality of education, effectiveness of education, successful communities, sense of superiority, threat, contempt, fear, parents' pressure, impulse control, reform of Ukrainian education.

Помогайбо Валентин Михайлович, кандидат біологічних наук, доцент, професор-консультант кафедри спеціальної освіти та соціальної роботи Полтавського національного педагогічного університету ім. В.Г. Короленка (Україна). ORCID: https://orcid.org/0000-0002-9828-2565

E-mail: vmpom@ukr.net; valmichpom@gmail.com

Pomohaibo Valentyn Mychailovych, candidate of science (biology), assistant professor, professor-consultant of Poltava National Pedagogical V. G. Korolenko University (Ukraine). ORCID: https://orcid.org/0000-0002-9828-2565

E-mail: vmpom@ukr.net; valmichpom@gmail.com 